\title{
Optimalisasi Kemampuan Penanganan Cedera Rumah Tangga dengan Metode Pemberian Booklet pada Warga Karang Rau Purwokerto
}

\author{
Nurul Fatwati Fitriana $^{1 *}$, Mustiah Yulistiani ${ }^{2}$ \\ 1*. Universitas Muhammdiyah Purwokerto, Jl. Soepardjo Roestam KM 7 Sokaraja, Indonesia 53181 \\ 2. Universitas Muhammdiyah Purwokerto, Jl. Soepardjo Roestam KM 7 Sokaraja, Indonesia 53181 \\ *e-mail : nurulfatwati90@gmail.com*
}

\begin{abstract}
Abstrak
Program pengabdian masyarakat ini sebagai perwujudan dari LPPM UMP dan Fakultas Ilmu Kesehatan dalam mendukung gerakan masyarakat sehat. Kegiatan ini dilakukan di desa Karang Rau pada tanggal 17 Januari 2019. Secara umum kegiatan ini dilakukan untuk sosialisasi penanganan kegawatdaruratan cedera rumah tangga yang biasa terjadi pada kehidupan sehari-hari. Target khusus kegiatan ini adalah untuk mengurangi angka morbiditas dan mortalitas yang disebabkan oleh cedera rumah tangga. Metode yang digunakan dalam pencapaian tujuan adalah penyuluhan menggunakan booklet, ceramah dan praktik pada responden serta dievaluasi menggunakan kuesioner pre dan post test. Hasil dari kegiatan ini adalah terjadi peningkatan pengetahuan responden tentang penanganan cedera rumah tangga.
\end{abstract}

Kata Kunci : Booklet, Cedera, Penyuluhan

\section{Pendahuluan}

Beberapa keadaan kegawatdaruratan yang sering di temui sehari hari dan masih mudah cara penanganannya namun masyarakat masih sering salah dalam penanganannya adalah luka, luka bakar, pingsan, Hipertermia atau demam, kelilipan dan kram. Tindakan yang salah akan menimbulkan angka kesakitan bagi penderita bahkan mungkin kematian apabila tidak di tangani secara tepat dan cepat. Kejadian gawat darurat dapat di artikan sebagai keadaan dimana seorang membutuhkan pertolongan segera karena apabila tidak mendapatkan pertolongan dengan segera maka dapat mengancam jiwanya atau menimbulkan kecacatan permanen (Media Aeculapius, 2007)

Luka merupakan keadaan dimana terjadi kerusakan dalam continuitas kulit dan jaringan di bawah kulit.(Panacea, 2012). Luka dalam kehidupan sehari-hari bisa didapatkan dari terjatuh, terkena pisau ketika memasak. Saat membicarakan terjadinya luka, maka biasanya selalu terkait dengan adanya perdarahan atau keluarnya darah pada daerah yang cedera. Jadi, pertolongan pertama yang dilakukan adalah dengan tujuan menghentikan perdarahan. Perdarahan yang terjadi terus menerus bisa menyebabkan ketidakseimbangan sirkulasi darah dalam tubuh dan akan berakibat shock. Penanganan selanjutnya bertujuan untuk pemeliharaan fungsi-fungsi tubuh dan menurunkan risiko infeksi (Andra, 2013). Tindakan pertama yang dilakukan pada cedera luka (lecet, gores) adalah dengan membersihkan dengan air bersih yang mengalir dan dilanjutkan dengan metode RICE management (Rest, Ice, Compress, Elevate) atau istirahatkan, kompres dengan es, tekan pada daerah yang luka, dan tinggikan luka lebih tinggi daripada jantung.

Luka bakar adalah luka yang terjadi karena adanya suhu yang panas, bisa api, air panas, dan sengatan listrik. Pada luka bakar karena api atau air panas, kebanyakan orang akan memberikan pertolongan pertama dengan cara memberikan pasta gigi atau minyak (Andra, 2013). Tindakan seperti itu salah karena pasta gigi atau minyak hanya akan memberikan sensasi dingin sementara dan akan segera membeku dan mengeras sehingga kulit yang terluka tidak bisa bernafas dan bisa mengakibatkan infeksi sekunder. Penanganan yang benar adalah dengan menyiram luka dengan air bersih yang mengalir.

Pingsan (Syncope) adalah suatu gejala (symptom) yang ditandai dengan hilangnya kesadaran yang bersifat sementara yang onsetnya secara tiba-tiba, disertai dengan tidak mampunyai kemampuan mempertahankan posisi tubuh dan menyebabkan aliran darah yang membawa nutrisi dan oksigen ke otak terganggu dan bersifat sementara. Kesalahan penanganan pingsan pada masyarakat umumnya, korban pingsan seringkali di kelilingi oleh orang banyak. Pertolongan pertama adalah dengan memindahkan korban dari penyebab pingsan (panas, keramaian), melonggarkan ikatan pakaian, membaringkan pada posisi supinasi supaya posisi kepala lebih rendah, jika tidak memungkinkan untuk berbaring,dudukkan korban di kursi dan minta korban untuk meletakkan kepalanya meringkuk di antara lutut dan minta bernafas dalam (Baroto,2007).

Cedera pada anak usia sekolah yang sering adalah lecet, terkilir, mimisan, memar, luka bakar, kelilipan dan terjatuh. Pertolongan pertama pada luka lecet yaitu dengan membersihkan dengan air bersih atau air yang diberi antiseptik (contoh : dettol), kemudian diberi obat merah. Pada memar, cukup dibersihkan dan diberi kompres dingin 
pada daerah yang memar. Pada terkilir, daerah yang cedera cukup diistirahatkan dan dikompres menggunakan air hangat, tidak perlu diurut. Pada mimisan, penderita cukup disuruh duduk dengan posisi menunduk, hidung ditekan untuk menghentikan perdarahan kemudian dikompres menggunakan air es (Tindakan yang tepat akan menurunkan angka kesakitan (Humardani, 2013)

Ketika kejadian gunung meletus yang dimana abu dari letusan gunung sampai ke Purwokerto, abu bisa mengakibatkan cedera pada mata. Seperti pada letusan yang terjadi beberapa waktu lalu, yaitu gunung Merapi, Gunung Slamet dan Gunung Kelud. Pada kejadian mata kemasukan debu (kelilipan), seringkali korban akan mengkucek-kucek mata yang terkena. Hal itu bisa menyebabkan mata akan terluka oleh gesekan debu serta mata akan terkena iritasi sekunder apabila tangan yang diguanakan untuk mengkucek tidak bersih. Penanganan sederhana yang benar adalah dengan mengkedip-kedipin mata kemudian di siram menggunakan air bersih yang mengalir (Andra, 2013).

Perumahan Karang Rau, terdapat $30 \mathrm{KK}$. Menurut studi pendahuluan pada beberapa warga perumahan , beberapa ibu rumah tangga belum lebih jelas terkait kejadian cedera yang sering terjadi di kehidupan sehari-hari. Fakultas Ilmu Kesehatan merupakan Fakultas dengan ciri khas kegawatdaruratannya. Idealnya, kesiagaan warga dalam menghadapi kejadian cedera yang terjadi di kehidupan sehari-hari dapat lebih di optimalkan dengan cara mengadakan pelatihan pada ibu-ibu rumah tangga supaya apabila terjadi cedera rumah tangga bisa dapat segera ditangani

\section{Metode}

Metode yang digunakan dalam kegiatan ini adalah pemberian kuesioner pre dan post test, ceramah dan praktik.

Tahapan dalam kegiatan ini adalah sebagai berikut :

a. Pengenalan dan Persiapan

Persiapan yang dilakukan adalah melakukan ijin dan penjelasan kepada ketua perkumpulan ibu-ibu dawis. Diskusi dilakukan bertujuan agar acara kegaiatan berlangsung dengan lancar pada hari pelaksanaan.

b. Mekanisme pelaksanaan pengabdian masyarakat

Pelaksanaan kegiatan dilakukan pada tanggal 17 Januari 2019. Penyuluh memberikan kuesioner pre test kepada responden. Setelah itu memberikan penjabaran tentang tindakan cedera rumah tangga dan penanganannya serta responden diberikan bookletnya. Dua minggu kemudian, dilakukan post test kepada responden. Jumlah responden adalah 25 orang.

\section{Hasil}

a. Karakteristik Peserta

Bagian ini menjelaskan karakteristik peserta yang terlibat. Dapat mencantumkan table yang menguraikan karakterirstik peserta.

Tabel 1. Distribusi frekuensi karateristik peserta pengabdian masyarakat

\begin{tabular}{|c|c|c|c|}
\hline No & Karakteristik Responden & $\mathrm{n}$ & $\%$ \\
\hline \multirow{4}{*}{1} & Jenis Kelamin & & \\
& Perempuan & 25 & 100 \\
& Laki-laki & 0 & 0 \\
\hline \multirow{4}{*}{2} & Tingkat Pendidikan & & \\
& SD & 0 & 0 \\
& SMP & 0 & 0 \\
& SMA & 15 & 60 \\
& PT & 10 & 40 \\
\hline \multirow{4}{*}{3} & Pekerjaan & 0 & 0 \\
& PNS & 20 & 80 \\
& Wiraswasta & 5 & 20 \\
\hline \multicolumn{2}{|c|}{ IRT } & 0 & 0 \\
\hline
\end{tabular}

Tabel 1. Menunjukkan bahwa distribusi peserta kegiatan pengabdian kepada masyarakat ini lsemuanya adalah berjenis kelamin yaitu perempuan, tingkat pendidikan terakhir yaitu SMA sebesar 60\%, dan pekerjaan sebagai wiraswasta sebesar $80 \%$.

b. Respon Peserta

Kuesioner untuk mengukur pengetahuan (pretest) diberikan dan posttest untuk mengetahui pengetahuan responden dikerjakan dengan baik. Setelah mengisi pretest, penyuluh melakukan praktik penanganan cedera rumah tangga kepada responden dan diikuti responden. Responden dengan antusias mengikuti penyuluhan dan menjawab pertanyaan secara lisan dengan baik. 


\section{c. Luaran kegiatan}

Pengetahuan rata-rata responden tentang penanganan kegawatdaruratan adalah sebesar 7,11\% (pretest) dan sebesar 86,3\% (post test). Evaluasi post test dilakukan setelah 2 minggu responden menerima booklet dari penyuluh. Upaya peningkatan pengetahuan kepada responden dilakukan oleh penyuluh menggunakan media ceramah, praktik dan pemberian booklet.

Tabel 2. Rerata Skor Pengetahuan Pretest Dan Posttest

\begin{tabular}{|c|c|c|}
\hline Variabel & $\mathrm{n}$ & $\begin{array}{c}\text { Mean (minimum- } \\
\text { maksimum) }\end{array}$ \\
\hline $\begin{array}{c}\text { Pengetahuan sebelum } \\
\text { intervensi }\end{array}$ & 25 & $\begin{array}{c}7,11 \\
(4-9)\end{array}$ \\
\hline Pengetahuan setelah intervensi & 25 & $\begin{array}{c}8,63 \\
(7-12)\end{array}$ \\
\hline
\end{tabular}

Media pembelajaran dapat mempengaruhi tingkat pemahaman seseorang. Media pembelajaran yang melibatkan indra penglihatan dan pendengaran dapat menjadi lebih efektif dalam meningkatkan pemahaman dan pengetahuan responden. Berdasarkan penelitian, pentransferan pengetahuan yang diterima olah otak adalah dari mata (75\%-85\%), sedangkan $13 \%-25 \%$ pengetahuan manusia didapatkan dari indera yang lain (Maulana, 2009) . Kegiatan ini memberikan materi berupa penyuluhan, praktik dan pemberian booklet untuk optimalisasi kemampuan dalam penanganan cedera. Hal ini sesuai dengan pendapat Yasmin dan Madanijah (2010) yang menyatakan bahwa penyuluhan merupakan salah satu pendidikan non formal, mampu mempengaruhi tingkat pengetahuan seseorang.

Menurut Rahman (2008) Pengetahuan dapat didapatkan dari pelatihan. Dengan pengetahuan yang dimiliki seseorang akan mendasari sikap dalam memberikan tindakan yang dapat dilakukan dengan lebih efektif. Kecepatan dan ketepatan tindakan pada waktu sebelum masuk ke rumah sakit dalam kejadian cedera sangat menentukan survivabilitas pasien (Herkutanto, 2007).

Notoatmodjo (2007) menjelaskan bahwa dengan semakin tinggi tingkat pengetahuan seseorang maka semakin tinggi pula orang memahami kegiatan untuk mencapai tujuan. Trimukaim (2007) cit Martono (2012) menjelaskan bahwa pengetahuan mempengaruhi sikap seseorang dalam mengambil suatu keputusan untuk melakukan yang terkait dengan masalah kesehatan yang sedang dihadapi.

Hasil pengabdian kepada masyarakat menunjukkan bahwa ada peningkatan pengetahuan penanganan kegawatdaruratan cedera rumah tangga setelah diberikan penyuluhan serta penambahan edukasi menggunakan booklet dibuktikan dengan adanya perbedaan rerata nilai pengetahuan penanganan cedera. Artinya, dalam kegaiatan ini meningkatkan pengetahuan peserta pengabdian dalam menangani kegawatan cedera rumah tangga. Tujuan program ini adalah masyarakat dapat melakukan penanganan cedera dengan baik, benar dan tepat. Penanganan cedera yang tepat dan cepat dapat mengurangi angka mortalitas dan morbiditas yang disebabkan oleh cedera rumah tangga (Emergency Nurses Association, 2018).

\section{Kesimpulan}

Terjadi peningkatan pengetahuan responden dibuktikan dengan kenaikan nilai pengetahuan responden dari 71,1 menjadi 86,3. Pengetahuan masih perlu ditingkatkan lagi menggunakan metode yang lain.

\section{Saran}

Diharapkan pihak terkait mengajarkan masyarakat awam untuk melakukan kegiatan pembelajaran kepada kader-kader kesehatan yang khusus mempelajari tentang cedera sehari-hari. Metode yang digunakan bisa menggunakan forum group discussion atau studi kasus.

\section{Daftar Pustaka}

Andra, S. W., \& Yessie, M. P. (2013). KMB 1 Keperawatan Medikal Bedah Keperawatan Dewasa Teori dan Contoh Askep. Yogyakarta: Nuha Medika.

Basmatika, I.A. (2012). Cedera Otak Sekunder. Denpasar : Universitas Udayana RSUP Sanglah. Baroto (2007). Penyebab terjadinya cedera. Jakarta: Penerbit

Emergency Nurses Associaton, (2018). Keperawatan Gawat Darurat dan Bencana Sheehy . Elsevier

Herkutanto, (2007) Aspek Medikolegal Pelayanan Gawat Darurat. Majalah Kedokteran Indonesia, Volume: 57, Nomor: 2, Pebruari. 
Pada Pasien Gawat Darurat Kecelakaan Lalulintas. Skripsi. Ponorogo : Universitas Muhammadiyah Ponorogo.

Kristiansen, Lossius, Kjetil, Petter, Steen, Gaarder, Pål A Næss (2011). Patients Referred to a Norwegian Trauma Centre: effect of transfer distance on injury patterns, use of resources and outcomes. Journal of Trauma Management \& Outcome.

Kapita Selekta Kedokteran Edisi 3 Jilid II. Jakarta: Media Aesculapius

Martono. (2012). Pengetahuan Kegawatdaruratan Trauma dan Sikap Posdaya dalam Merencanakan Tindakan Trauma. Jurnal Terpadu Ilmu Kesehatan, Jilid 1. Hlm 29-34

Morton,et al. (2012). Keperawatan kritis pendekatan asuhan holistik. Vol.1. Jakarta: kedokteran EGC.

Notoatmodjo, S. (2003). Ilmu Kesehatan Masyarakat Prinsip-Prinsip Dasar. Jakarta : Rineka Cipta

Notoatmodjo, S. (2007). Promosi kesehatan dan ilmu perilaku. Jakarta : Rineka Cipta

Panacea, (2012). Tim Bantuan Medis Mahasiswa. Jakarta : EGC

Rahman, N. 2008. Pengetahuan Perawat Tentang Kegawatan Nafas dan Tindakan Resusitasi Pada Neonatus yang Mengalami Kegawatan di Ruang NICU, Perinatologi dan anak RSUD Gunung Jati Cirebon. Skripsi

Yasmin, G., Madanijah, S. (2010). Perilaku Penjaja Pangan Jajanan Anak Sekolah Terkait gizi dan Keamanan Pangan di Jakarta dan Sukabumi. Jurnal Gizi dan Pangan. Vol. 5 No. 1, p: 148-157 